\title{
WYKŁADNIA FUNKCJONALNA W ORZECZNICTWIE SĄDÓW ADMINISTRACYJNYCH
}

I. Istotnymi elementami uzasadnienia wyroku sądu administracyjnego, oprócz przedstawienia stanu sprawy, zarzutów podniesionych w skardze oraz stanowisk pozostałych stron, sa wskazanie podstawy prawnej podjętego rozstrzygnięcia oraz jej wyjaśnienie. Jak zauważa się w orzecznictwie sądowym, w uzasadnieniu wyroku powinno znaleźć się nie tylko określenie treści przepisów obowiązujących $\mathrm{w}$ danej sprawie, lecz także ich interpretacja $\mathrm{w}$ odniesieniu do analizowanego stanu faktycznego ${ }^{1}$. Bez podania podstawy prawnej oraz jej wyjaśnienia uzasadnienie wyroku pozbawione byłoby jednego z konstytutywnych elementów. Brak tego składnika w wypadku uzasadnienia wyroku sądu I instancji stanowiłby $\mathrm{z}$ cała pewnością skuteczny zarzut kasacyjny, jako naruszenie art. 174 pkt 2 p.p.s.a ${ }^{2}$ w zw. z art. $141 \S 4$ p.p.s.a. ${ }^{3}$ Trudno wyobrazić sobie, aby jakiekolwiek uzasadnienie orzeczenia Naczelnego Sądu Administracyjnego (NSA) nie zawierało wyjaśnienia podstawy prawnej podjętego rozstrzygnięcia. Poza tym biorąc pod uwagę, że konsekwencja rozważań prawnych pozostaje sformułowanie przez sąd oceny prawnej i wskazań co do dalszego postępowania, ich zupełny brak uniemożliwiałby prawidłowe zastosowanie przez sąd art. 153 p.p.s.a. ${ }^{4}$ Nie można również tracić z pola widzenia pozaprawnych funkcji wypełnianych przez pisemne uzasadnienie zapadłego $\mathrm{w}$ sprawie orzeczenia ${ }^{5}$.

\footnotetext{
${ }^{1}$ Wyrok NSA z 8 września 2010 r., sygn. akt II OSK 1385/09, Lex, nr 746503. Zob. też wyroki NSA: z 3 sierpnia 2010 r., sygn. akt I OSK 1545/09, Lex, nr 745079 oraz z 30 marca 2010 r., sygn. akt I FSK 376/09, Lex, nr 593941. B. Dauter stwierdza wyraźnie, że wyjaśnienie podstawy prawnej rozstrzygnięcia nie może polegać na zacytowaniu treści danego przepisu bez dokonania jego wykładni w odniesieniu do konkretnego stanu faktycznego. Zob. B. Dauter, Metodyka pracy sędziego sadu administracyjnego, Warszawa 2011, s. 461. Zob. też B. Adamiak, J. Borkowski, Metodyka pracy sędziego w sprawach administracyjnych, Warszawa 2009, s. 265-266.

${ }^{2}$ Ustawa z 30 sierpnia 2002 r. - Prawo o postępowaniu przed sądami administracyjnymi, Dz. U. 2002, Nr 153, poz. 1270 ze zm. (dalej: p.p.s.a.).

${ }^{3}$ Postanowienie NSA z 23 listopada 2010 r., sygn. akt II GSK 976/10, Lex, nr 742972; wyroki NSA: z 5 listopada 2010 r., sygn. akt II GSK 935/09, Lex, nr 746342; z 13 października 2010 r., sygn. akt II FSK 1038/09, Lex, nr 745440; z 5 października 2010 r., sygn. akt II FSK 1240/10, Lex, nr 745579; z 15 czerwca 2010 r., sygn. akt II OSK 986/09, Lex, nr 597986.

${ }^{4}$ Ocena prawna wynika $\mathrm{z}$ uzasadnienia wyroku sądu i dotyczy wykładni przepisów prawa oraz sposobu ich zastosowania w rozpoznawanej sprawie. Zob. wyrok NSA z 1 września 2010 r., sygn. akt II OSK 518/09, Lex, nr 746901. Zob. też B. Dauter, op. cit., s. 466-468; J. P. Tarno, Prawo o postępowaniu przed sadami administracyjnymi. Komentarz, Warszawa 2010, s. 358-359.

${ }^{5}$ Jak bowiem wskazał NSA w jednym z orzeczeń, uzasadnienie wyroku w każdej sprawie ma nie tylko umożliwić stronom poznanie argumentów leżących u podstaw procesu wnioskowania, który
} 
Celem niniejszego opracowania jest analiza wypadków odwoływania się przez sądy administracyjne w podejmowanych rozstrzygnięciach do rezultatów wykładni funkcjonalnej; badania objęły okres od początku 2009 do połowy 2011 r. Taki zakres czasowy analizy pozwoli na dokonanie rzetelnej identyfikacji współczesnych poglądów dotyczących wykładni funkcjonalnej sformułowanych $\mathrm{w}$ orzecznictwie sądowym. Poza tym wybrany przedział czasowy obejmuje okres przypadający kilka lat po reformie sądownictwa administracyjnego, której głównym założeniem było utworzenie dwuinstancyjnego postępowania sądowego, stosownie do art. 236 ust. 2 Konstytucji $\mathrm{RP}^{6}$ (ustawodawca został w nim zobowiązany do uchwalenia aktów prawnych wprowadzających w życie zasadę instancyjności postępowania sądowego w odniesieniu do postępowania przed sądami administracyjnymi przed upływem 5 lat od dnia wejścia w życie Konstytucji RP). Utworzenie drugiej instancji sądowej stanowiło istotny przełom nie tylko $\mathrm{z}$ ustrojowego oraz procesowego punktu widzenia. Miało ono również wpływ na sposób wyjaśniania podstawy prawnej zapadających rozstrzygnięć, szczególnie wojewódzkich sądów administracyjnych, których orzeczenia podlegaja kontroli NSA. Po upływie kilku lat od wprowadzenia reformy w życie można mówić o pewnej stabilizacji orzecznictwa sądowego również pod względem sposobu prezentowania w pisemnych uzasadnieniach rozważań prawnych oraz faktycznych.

W odniesieniu do stosowania prawa administracyjnego ze względu na jego cechy szczególne, w tym wielowarstwowość źródeł, ścisły związek z realizowaną przez administrację polityką oraz rozległy przedmiot regulacji ${ }^{7}, \mathrm{w}$ doktrynie wyrażone zostało stanowisko, że dokonując jego wykładni niezbędne jest każdorazowe odwołanie się przez interpretatora do pozajęzykowych dyrektyw interpretacyjnych, w tym dyrektyw funkcjonalnych. Z kolei rezultatom wykładni językowej nie należy nadawać najsilniejszego i przesądzającego znaczenia, pozostającego $\mathrm{w}$ sprzeczności $\mathrm{z}$ efektami wykładni systemowej oraz celowościowej ${ }^{8}$. Wyjątkowego znaczenia metody wykładni funkcjonalnej

doprowadził do określonego rozstrzygnięcia. Powinno ono mieć też walor informacyjny dla szerokiego kręgu odbiorców przy uwzględnieniu faktu, że orzecznictwo sądów administracyjnych wytycza kierunki działania organów administracji. W państwie prawa ważne jest ponadto, aby rozstrzygnięcia uzasadniane były w sposób pogłębiający zaufanie obywateli do wymiaru sprawiedliwości sprawowanego przez sądy. Zob. wyrok NSA z 7 lipca 2010 r., sygn. akt I OSK 592/10, Lex, nr 672918.

${ }^{6}$ Ustawa z 2 kwietnia 1997 r. - Konstytucja Rzeczypospolitej Polskiej, Dz. U. 1997, Nr 78, poz. 483 ze zm. (dalej: Konstytucja RP). Ustawa z 25 lipca 2002 r. - Prawo o ustroju sądów administracyjnych (Dz. U. 2002, Nr 153, poz. 1269) oraz z 30 sierpnia 2002 r. p.p.s.a. i przepisy wprowadzające ustawę - Prawo o ustroju sądów administracyjnych i ustawę - Prawo o postępowaniu przed sądami administracyjnymi (Dz. U. 2002, Nr 153, poz. 1271) weszły w życie 1 stycznia 2004 r.

${ }^{7}$ Szerzej na temat genezy oraz szczególnych właściwości prawa administracyjnego zob. Z. Duniewska, Prawo administracyjne - wprowadzenie, w: R. Hauser, Z. Niewiadomski, A. Wróbel (red.), System prawa administracyjnego, t. I: Instytucje prawa administracyjnego, Warszawa 2010, s. 63-192. Zob. też J. P. Tarno, Naczelny Sad Administracyjny a wyktadnia prawa administracyjnego, Warszawa 1999, s. 49-50; W. Piątek, Podstawy skargi kasacyjnej $w$ postepowaniu sadowoadministracyjnym, Warszawa 2011, s. 183-187.

${ }^{8}$ W. Jakimowicz, O postulacie tzw. ,petnej wyktadni $w$ prawie” administracyjnym, „Casus” 2007, z. 44, s. 16. Pomijanie celu regulacji prawnej i ustalanie jej znaczenia wyłącznie za pomocą analizy słów uznane zostało za główny i najczęściej występujący błąd w rozumieniu i stosowaniu prawa administracyjnego. Zob. E. Smoktunowicz, Orzecznictwo Sadu Najwyższego i Naczelnego Sadu Administracyjnego: kodeks postępowania administracyjnego, Warszawa 1994, s. 32. 
$\mathrm{w}$ prawie administracyjnym doktryna upatruje $\mathrm{w}$ dążeniu do osiagnięcia jednego $\mathrm{z}$ podstawowych jego założeń, jakim jest realizacja celu publicznego. Uwzględnianie $\mathrm{w}$ procesie interpretacji tej wykładni prowadzi ponadto do kompromisu pomiędzy dwiema metodami wykładni: statycznej a dynamicznej, służąc poszanowaniu pewności oraz elastyczności prawa ${ }^{9}$. Równocześnie wskazuje się jednak, że szczególne miejsce wykładni funkcjonalnej w prawie administracyjnym nie może prowadzić do konfliktu z rzeczywistą treścią normy wypływająca $\mathrm{z}$ interpretowanego tekstu ${ }^{10}$. W ten sposób prymat dla ostatecznego rezultatu wykładni nadawany jest interpretacji językowej, gdyż pozajęzykowe reguły wykładni nie moga wykraczać poza dopuszczalne z językowego punktu widzenia możliwości interpretacji prawa. Jednakże współcześnie coraz wyraźniej podnosi się, że wykładnia językowa, jako pierwszy pod względem chronologicznym etap interpretacji, nie korzysta jednocześnie w sposób automatyczny z prymatu pod względem wagi formułowanych argumentów ${ }^{11}$. Powyższe wątpliwości interpretacyjne dotyczące miejsca oraz znaczenia wykładni funkcjonalnej dla prawidłowego przeprowadzenia procesu interpretacji znajduja swoje odzwierciedlenie w poszczególnych orzeczeniach sądów administracyjnych. Zadaniem niniejszego opracowania pozostaje $\mathrm{w}$ związku z tym między innymi odkrycie istniejących $\mathrm{w}$ tej mierze różnic, zdefiniowanie dominujących $\mathrm{w}$ orzecznictwie tendencji oraz sformułowanie wniosków odnośnie do ich koherentności z postulatem szerokiego sięgania do rezultatów wykładni funkcjonalnej w ramach interpretacji prawa administracyjnego. Udzieleniu odpowiedzi na powyższe problemy badawcze służyć będzie analiza 137 orzeczeń sądów administracyjnych; za kryterium ich wyselekcjonowania przyjęto okoliczność odwoływania się przez sądy administracyjne do rezultatów wykładni funkcjonalnej w pisemnych uzasadnieniach podejmowanych rozstrzygnięć albo argumentacji przemawiającej za niezasadnością odwołania się do tego rodzaju dyrektyw interpretacyjnych.

II. Dla celów prowadzonych rozważań należy podkreślić, że wymiar sprawiedliwości sprawowany przez sądy administracyjne polega na kontroli działalności administracji publicznej przy uwzględnieniu kryterium zgodności

${ }^{9}$ W. Jakimowicz, Wyktadnia $w$ prawie administracyjnym, Warszawa 2006, s. 183-185.

${ }^{10} \mathrm{~K}$. Lewandowska, T. Lewandowski, Wykładnia celowościowa i językowa $w$ prawie administracyjnym. Wytyczne doktryny i praktyczny przyktad ich zastosowania, ,Samorząd Terytorialny” 2010, z. 9, s. 20. Pogląd ten aprobuje R. Mastalski, jednocześnie wskazując, że ze względu na to, iż wykładnia ustawy ma miejsce w mniej lub bardziej odległym czasie od dnia jej wejścia w życie, samo brzmienie słów ustawy nie jest często wystarczające do określenia jej ratio legis. Ponadto autor zwraca uwagę na znaczny wzrost znaczenia wykładni celowościowej po dniu wejścia Polski do Unii Europejskiej. Zob. R. Mastalski, Stosowanie prawa podatkowego, Warszawa 2008, s. 92-96. Natomiast B. Brzeziński, akcentując istotne znaczenie wykładni językowej w procesie wykładni prawa podatkowego, dopuszcza możliwość dokonania korekty rezultatu osiągniętego przy zastosowaniu dyrektyw językowych na skutek odwołania się do wykładni celowościowej. Zob. B. Brzeziński, Szkice z wyktadni prawa podatkowego, Gdańsk 2002, s. $59-61$.

11 Jak bowiem wskazał M. Zieliński, jednym z mitów jest nadawanie dyrektywom językowym najsilniejszego znaczenia ze względu na końcowy rezultat procesu interpretacji. W stanowisku tym pomieszano chronologię stosowania typów dyrektyw z ich waga. Szerzej zob. M. Zieliński, Osiemnaście mitów w myśleniu o wyktadni prawa, „Palestra” 2011, z. 3-4, s. 27-28. Zob. też wyrok WSA w Poznaniu z 1 czerwca 2011 r., sygn. akt IV SA/Po 254/11, Centralna Baza Orzeczeń Sądów Administracyjnych, dostępna na: www.orzeczenia.nsa.gov.pl (dalej: CBOSA). 
z prawem aktów lub innego rodzaju czynności z zakresu administracji publicznej. W ten sposób sądy administracyjne dokonują powtórnie wykładni znajdujących zastosowanie $\mathrm{w}$ danej sprawie przepisów prawa administracyjnego celem sformułowania zwrotu stosunkowego dotyczącego zgodności $\mathrm{z}$ prawem działania administracji publicznej ${ }^{12}$. Odwoływanie się w tym zakresie do rezultatów wykładni funkcjonalnej nie służy zastapieniu organów administracji w końcowym załatwieniu sprawy administracyjnej, ale wieloaspektowa kontrola ich działania powinna umożliwić tym organom rozstrzygnięcie sprawy administracyjnej zgodnie $\mathrm{z}$ prawem ${ }^{13}$. Takiego rodzaju sprawowanie wymiaru sprawiedliwości przez sądy administracyjne skutkuje powstawaniem wątpliwości dotyczących miejsca, znaczenia i ewentualnych granic wykładni funkcjonalnej oraz szczegółowych dyrektyw funkcjonalnych, na które powołuja się sądy administracyjne w swoim orzecznictwie. Jak zauważono bowiem w doktrynie, wykładnia kontrolna sądu administracyjnego nie realizuje się w modelu identycznym $\mathrm{z}$ modelem sądowej kontroli wykładni operatywnej dokonywanej przez sądy powszechne. Kontrola z punktu widzenia zgodności $\mathrm{z}$ prawem nadaje większe znaczenie przepisom prawnym jako argumentom walidacyjnym, a w zakresie wykładni - jest punktem odniesienia kontroli rekonstrukcji normatywnej decyzji administracyjnej. Na obszarze przebiegu wykładni kontrolnej, przy zachowaniu modelu kolejności wykorzystywanych reguł, umożliwia to wykorzystanie zasady interpretatio cessat in claris jako elementu ograniczenia postulatu sięgania po cały katalog reguł wykładni ${ }^{14}$.

Przedstawiony pogląd tym bardziej skłania do przeprowadzenia analizy procesu wykładni dokonywanego przez sądy administracyjne w uzasadnieniach poszczególnych orzeczeń pod kątem częstotliwości oraz kontekstu, w którym sądy te odwołuja się do reguł funkcjonalnych, jak również znaczenia zastosowania tego rodzaju dyrektyw dla podejmowanych rozstrzygnięć. Aprobując opinię, że sądy administracyjne dokonuja kontroli administracji wyłącznie z punktu widzenia oceny zgodności procesu decyzyjnego z normami prawnymi mającymi charakter norm odpowiednio kompetencyjnych, proceduralnych i materialnych, nie można jednak automatycznie stwierdzić, że są one zwolnione z dokonywania kontroli legalności prawidłowego rozumienia przez organy administracji pozasystemowych kryteriów stanowiących elementy składowe regulacji prawnych. Sam proces stosowania prawa zawiera w sobie konieczność odwoływania się przez skład orzekający do szeregu ocen

\footnotetext{
${ }^{12} \mathrm{Na}$ temat zwrotów stosunkowych zob. J. Wróblewski, Zwroty stosunkowe - wypowiedzi o zgodności $z$ norma, „Zeszyty Naukowe Uniwersytetu Łódzkiego”, Nauki Humanistyczno-Społeczne 1969, z. 62, s. 5-16.

${ }^{13}$ Zob. R. Hauser, A. Kabat, Wtaściwość sadów administracyjnych, ,Ruch Prawniczy, Ekonomiczny i Socjologiczny" 2004, z. 2, s. 25-26; R. Hauser, Nieporozumienia wokót charakteru orzeczeń sadów administracyjnych, w: J. Góral (red.), Ratio est anima legis. Księga jubileuszowa ku czci Profesora Janusza Trzcińskiego, Warszawa 2007, s. 238-240.

${ }^{14}$ L. Leszczyński, Orzekanie przez sady administracyjne a kontrola wyktadni prawa, ,Zeszyty Naukowe Sądownictwa Administracyjnego" 2010, z. 5-6, s. 277. Zob. też idem, Sadowa kontrola administracji a ,kontrolna wyktadnia operatywna” prawa administracyjnego, w: A. Choduń, S. Czepita (red.), W poszukiwaniu dobra wspólnego. Ksiega jubileuszowa Profesora Macieja Zielińskiego, Szczecin 2010, s. 317-320. Na problem ten zwrócił również uwagę O. Bogucki w monografii Wyktadnia funkcjonalna $w$ działalności najwyższych organów władzy sqdowniczej, Szczecin 2011, s. 229.
} 
pozaprawnych ${ }^{15}$. Natomiast przy interpretacji przepisów prawnych należy każdorazowo brać pod uwagę powszechnie akceptowane normy moralne, zasady sprawiedliwości i słuszności ${ }^{16}$. Poza tym nie można abstrahować od tego, że prawodawca, odsyłając do kryteriów pozaprawnych, tworzy w ten sposób konstrukcję normatywną, w oparciu o którą organ administracji, stosując prawo w sposób wiążący, określa konsekwencje normatywne ustalonego stanu faktycznego. Sąd administracyjny, orzekając o zgodności z prawem określonego rodzaju działalności administracji publicznej, nie może być w procesie kontroli ograniczany jedynie do pojęcia legalności rozumianego w sposób niezwykle formalny. Kierunek zgodnego z prawem działania administracji wyznaczaja, oprócz regulacji szczegółowych, także przepisy określające zadania, cele oraz kryteria działania organów administracji. Istotne znaczenie w procesie interpretacji odgrywają również zasady prawa wspólnotowego, przepisy konstytucyjne oraz zasady ogólne postępowania administracyjnego. Tego rodzaju elementy składowe systemu prawnego prowadzą do zwiększenia znaczenia pozajęzykowych reguł wykładni nie tylko w orzecznictwie organów administracji, lecz również sądów administracyjnych ${ }^{17}$. Przyjmując tego rodzaju kryteria normatywne, sąd administracyjny w swojej działalności orzeczniczej powinien ocenić prawidłowe rozumienie tych reguł przez organy administracji, ale nie w celu narzucenia administracji własnej aksjologii prawnej, lecz dokonania wszechstronnej kontroli zaskarżonego aktu lub czynności z zakresu administracji publicznej nieograniczonej jedynie do wąskiego rozumienia przede wszystkim norm materialnoprawnych ${ }^{18}$. W ten sposób sąd powinien

15 J. Wróblewski, Oceny $w$ prawie $i$ oceny prawa, ,Studia Prawnicze” 1970, z. 24, s. 11-19; Z. Ziembiński, Wstęp do aksjologii dla prawników, Warszawa 1990, s. 207-211.

${ }^{16}$ L. Morawski, Zasady wyktadni prawa, Toruń 2006, s. 147. W związku z tym A. Gomułowicz wskazuje wyraźnie, że idea autorytetu prawa musi być silnie zakotwiczona w systemie wartości uniwersalnych. Prawo jest zjawiskiem społecznym, a to oznacza, że musi podlegać ocenie także z moralnego, a więc etycznego punktu widzenia. Odwołania się do tetycznego uzasadnienia norm prawnych nie można uznać za jedyne i wyłączne kryterium, które rozstrzyga o obowiązywaniu norm, przede wszystkim dlatego, że ważną funkcję spełnia także czynnik uzasadnienia aksjologicznego norm. Zob. A. Gomułowicz, Aspekt prawotwórczy sadownictwa administracyjnego, Warszawa 2008, s. 30 i 91. Podobnie w orzecznictwie sądowym wskazuje się na obowiązywanie takich fundamentalnych wartości, jak sprawiedliwość, poszanowanie prawa własności, proporcjonalność stosowanych środków prawnych przy rozstrzygnięciach negatywnych (zob. wyrok NSA z 14 lipca 2009 r., sygn. akt I OSK 1302/08, Lex, nr 552299), czy też ogólnie zauważa się, że dokonując wykładni przepisów, nie można abstrahować od racji aksjologicznych, które uzasadniały uchwalenie przez ustawodawcę określonej regulacji. Zob. wyrok NSA z 23 marca 2011 r., sygn. akt I FSK 764/10, CBOSA.

17 Taki sam pogląd w odniesieniu do obecności w tekście prawnym generalnych klauzul odsyłających sformułował L. Leszczyński w monografii Stosowanie generalnych klauzul odsytajacych, Kraków 2001, s. 141-144. Z kolei na temat roli zasad ogólnych w orzecznictwie sądów administracyjnych zob. W. Piątek, Zasady ogólne Kodeksu postępowania administracyjnego jako podstawa skargi kasacyjnej $w$ postępowaniu sadowoadministracyjnym, w: J. Niczyporuk (red.), Kodyfikacja postępowania administracyjnego. Na 50-lecie k.p.a., Lublin 2010, s. 625-628.

${ }^{18}$ L. Leszczyński wskazuje w tej materii, że legalistyczny model kontroli sprawowanej przez sądy administracyjne ogranicza odnoszenie się do argumentu z aksjologii otwartej. Sąd administracyjny nie dokonuje bowiem samodzielnej interpretacji kryteriów otwartych w postaci generalnych klauzul odsyłających, kontrolując co najwyżej sposób ustalenia ich treści, dokonanie ,wyważenia aksjologicznego" oraz sposobu uzasadnienia powyższych ustaleń. Zob. L. Leszczyński, Orzekanie przez sady administracyjne..., s. 275. Zob. też wyrok NSA z 25 września 2009 r., sygn. akt I OSK 1403/08, CBOSA. Sąd administracyjny w każdym przypadku powinien dokonać samodzielnej interpretacji owych otwartych kryteriów, do których w sposób wyraźny odsyła prawodawca, gdyż kontrola ograniczona jedynie do elementów legalistycznych przestałaby spełniać swoją rolę, którą jest wszechstronne dokonanie kontroli 
odwołać się do dyrektyw funkcjonalnych, których ciężar gatunkowy może doprowadzić nawet do przełamania językowego rozumienia interpretowanej regulacji prawnej.

III. Przechodząc do analizy wykładni funkcjonalnej w poszczególnych orzeczeniach sądów administracyjnych, należy przypomnieć, że sam termin „wykładnia funkcjonalna” po raz pierwszy został wprowadzony do dyskursu naukowego przez Jerzego Wróblewskiego w 1959 r. ${ }^{19}$, jako odwołanie się w procesie interpretacji przepisu do „kontekstu funkcjonalnego”. W skład kontekstu funkcjonalnego wchodzą: ustrój ekonomiczny i społeczno-polityczny, w którym dana norma obowiązuje, ogólna kultura społeczeństwa wyrażana w przyjętych w nim ocenach i normach społecznych, cele społeczno-polityczne wysuwane przez grupy rządzące $\mathrm{w}$ społeczeństwie, zjawiska cywilizacyjne, w związku z którymi reguluje się zachowanie ludzi w społeczeństwie, takie jak technika komunikacyjna i sanitarna. W zależności od konkretnej sytuacji, zdaniem J. Wróblewskiego, oddziałuja na interpretatora rozmaite elementy tego kontekstu ${ }^{20}$. Odmienny sposób rozumienia wykładni funkcjonalnej zaprezentował Z. Ziembiński, wskazując, że jej dyrektywy nakazują w przypadkach, gdy przepis albo zespół przepisów jest wieloznaczny, odrzucić te jego znaczenia, przy których odtworzona z tekstu prawnego norma nie znajdowałaby uzasadnienia aksjologicznego albo nakazywałaby czynić coś, co w świetle ocen przypisywanych prawodawcy zasługiwałoby na potępienie, a przyjąć takie znaczenie przepisu, przy którym można byłoby wskazać odpowiednie uzasadnienie aksjologiczne zrekonstruowanej normy ${ }^{21}$. Oba wskazane ujęcia maja istotne znaczenie dla pojmowania wykładni funkcjonalnej $\mathrm{w}$ orzecznictwie sądów administracyjnych, odsyłając do problematyki wartości w wykładni prawa, z jednej strony przez uwzględnienie rzeczywistych problemów interpretacyjnych natury pozajęzykowej, a z drugiej - odnosząc proces wykładni do abstrakcyjnie rozumianego racjonalnego prawodawcy. Współcześnie przyjmuje się, że w ramach kontekstu funkcjonalnego powinny być uwzględniane wartości przyjmowane $\mathrm{w}$ sposób możliwie jak najbardziej powszechny, mające jak najlepsze uzasadnienie na gruncie określonej kultury, zarówno ogólnej, jak i prawnej ${ }^{22}$. Jednocześnie w orzecznictwie sądowym wykładnia funkcjonalna

aktu lub czynności z zakresu administracji publicznej pod względem zgodności z prawem rozumianym jako cały system, uwzględniający również obowiązujące reguły aksjologiczne (w tym unijne) oraz konstytucyjne.

${ }^{19}$ Aczkolwiek, jak wskazuje się w doktrynie, już na gruncie pierwszej polskiej koncepcji wykładni prawa autorstwa E. Waśkowskiego uwzględniane były niektóre z wskazywanych przez J. Wróblewskiego elementów kontekstu funkcjonalnego. Szerzej zob. M. Zieliński, O. Bogucki, A. Chodun, S. Czepita, B. Kanarek, A. Municzewski, Zintegrowanie polskich koncepcji wyktadni prawa, „Ruch Prawniczy, Ekonomiczny i Socjologiczny" 2009, z. 4, s. 30.

${ }^{20}$ J. Wróblewski, Zasady teorii wyktadni prawa ludowego, Warszawa 1959, s. 353. Zob. też idem, Sadowe stosowanie prawa, Warszawa 1988, s. 140-149.

${ }^{21}$ Z. Ziembiński, Logika praktyczna, Warszawa 1975, s. 251. Tak wyroki: WSA w Bydgoszczy z 11 maja 2011 r., sygn. akt II SA/Bd 311/11, CBOSA; NSA z 2 września 2008 r., sygn. akt I FSK 1017/07, CBOSA oraz z 22 lipca 2008 r., sygn. akt I FSK 938/07, CBOSA.

${ }^{22}$ Pisząc o obiektywizacji wartości, M. Zieliński, O. Bogucki, A. Choduń, S. Czepita, B. Kanarek i A. Municzewski, zauważają, że jej źródłem pozostaje powszechność uznawania określonej wartości na gruncie kulturowym, deklaracja ustrojodawcy co do podstawowego charakteru tej wartości przez 
utożsamiana jest często $\mathrm{z}$ wykładnią celowościową ${ }^{23}$, podczas gdy cel regulacji prawnej stanowi tylko jeden $\mathrm{z}$ elementów kontekstu funkcjonalnego, nie wypełniając w zupełności jego zakresu.

IV. Doniosłym zagadnieniem związanym z omawiana problematyka jest pojmowanie wykładni funkcjonalnej jako koniecznego stadium procesu interpretacyjnego dokonywanego przez sądy administracyjne. W orzecznictwie nadal mocno akcentuje się prymat wykładni językowej nad pozajęzykowymi dyrektywami interpretacyjnymi, do których należy się odwołać jedynie w sytuacji powstania wątpliwości czy też niejednoznaczności otrzymanego rezultatu wykładni językowej. Sądy odwołują się w takiej sytuacji do paremii clara non sunt interpretanda ${ }^{24}$, wskazując niekiedy wyraźnie, że w sytuacji jasnego brzmienia regulacji prawnej nie zachodzi konieczność dokonywania wykładni przepisów ${ }^{25}$. Drugi z wyróżnionych sposobów rozumienia powyższej dyrektywy kładzie nacisk na jej antyinicjujący charakter, który w sytuacji jasnego językowego rozumienia tekstu prawnego zakazuje dalszego prowadzenia procesu interpretacji. Jednocześnie w judykaturze zwraca się uwagę na kontrowersyjność oraz zawodność powyższej dyrektywy i weryfikuje ustalenia wykładni językowej, wykorzystując dyrektywy wykładni systemowej oraz funkcjonalnej ${ }^{26}$. W orzecznictwie zwraca się także uwagę, że ostatnim etapem procesu wykładni jest dekodowanie normy prawnej i osiągnięcie jej jednoznacznego rezultatu, a nie jedynie odczytanie tekstu przepisu prawa, co

wskazanie jej w Konstytucji, deklaracje prawodawcy co do celu, który ma zostać osiagnięty, lub innej wartości, która ponadto ma być uwzględniona, zamieszczone w preambule do określonego aktu normatywnego. Szerzej zob. M. Zieliński, O. Bogucki, A. Choduń, S. Czepita, B. Kanarek, A. Municzewski, op. cit., s. 32-34. Z kolei na temat typologii celów przypisywanych tekstom prawnym w orzecznictwie SN zob. T. Gizbert-Studnicki, Wyktadnia celowościowa, „Studia Prawnicze” 1985, z. 3-4, s. $56-60$.

${ }^{23} \mathrm{~W}$ szeregu orzeczeń termin ,wykładnia funkcjonalna” utożsamiany jest wprost z ,,wykładnia celowościową” albo ,względami celowości”. Zob. wyroki: WSA w Warszawie z 25 listopada 2010 r., sygn. akt I SA/Wa 1182/10, CBOSA; WSA w Krakowie z 2 lutego 2010 r., sygn. akt II SAB/Kr 112/09, CBOSA.

${ }^{24}$ Postanowienia NSA: z 20 stycznia 2011 r., sygn. akt II GSK 1496/10, CBOSA; z 14 lipca 2010 r., sygn. akt II GSK 752/10, CBOSA i z 9 grudnia 2009 r., sygn. akt II GSK 1014/09, CBOSA. Wyroki: WSA w Bydgoszczy z 11 maja 2011 r., sygn. akt II SA/Bd 311/11, CBOSA; WSA we Wrocławiu z 6 kwietnia 2011 r., sygn. akt III SA/Wr 19/11, CBOSA; NSA z 16 grudnia 2010 r., sygn. akt II FSK 1409/09, CBOSA; WSA w Warszawie z 30 września 2010 r., sygn. akt VIII SA/Wa 419/10, CBOSA; NSA z 9 września 2010 r., sygn. akt I OSK 404/10, CBOSA; NSA z 20 lipca 2010 r., sygn. akt II GSK 1045/09, CBOSA; WSA w Warszawie z 21 maja 2010 r., sygn. akt III SA/Wa 133/10, CBOSA; WSA w Olsztynie z 28 kwietnia 2010 r., sygn. akt II SA/Ol 79/10, CBOSA; NSA z 22 kwietnia 2010 r., sygn. akt II OSK 300/10, CBOSA; NSA z 12 lutego 2010 r., sygn. akt II FSK 521/09, CBOSA; NSA z 20 stycznia 2010 r., sygn. akt I OSK 354/08, CBOSA; NSA z 29 kwietnia 2009 r., sygn. akt II OSK 650/08, CBOSA; NSA z 12 stycznia 2009 r., sygn. akt I OSK 72/08, CBOSA.

${ }^{25}$ Wyroki: NSA z 14 kwietnia 2011 r., sygn. akt I OSK 1903/10, CBOSA; WSA w Warszawie z 12 kwietnia 2011 r., sygn. akt III SA/Wa 2071/10, CBOSA; NSA z 16 marca 2011 r., sygn. akt I OSK 2097/10, CBOSA; NSA z 23 listopada 2010 r., sygn. akt II GSK 1210/10, CBOSA.

${ }^{26}$ Wyroki: WSA we Wrocławiu z 28 kwietnia 2011 r., sygn. akt II SA/Wr 739/10, CBOSA; WSA w Poznaniu z 24 marca 2011 r., sygn. akt IV SA/Po 1065/10, CBOSA; WSA w Warszawie z 10 lutego 2011 r., sygn. akt VII SA/Wa 2184/10, CBOSA; WSA w Warszawie z 20 grudnia 2010 r., sygn. akt III SA/Wa 1679/10, CBOSA; WSA we Wrocławiu z 26 kwietnia 2010 r., sygn. akt II SA/Wr 86/10, CBOSA; NSA z 18 stycznia 2010 r., sygn. akt I SA/Wr 1616/09, CBOSA oraz postanowienie NSA z 9 kwietnia 2009 r., sygn. akt II FSK 1885/07, CBOSA. 
wyraża się w zasadzie interpretatio cessat in claris $^{27}$. W ten sposób paremia clara non sunt interpretanda nabiera nowego, antykontynuacyjnego znaczenia w sytuacji uzyskania jednoznacznego wyniku interpretacji. Wyróżnić można także nurt orzecznictwa, w którym - zgodnie z paremia omnia sunt interpretand $a^{28}$ - sąd już $\mathrm{z}$ samego założenia dokonuje wykładni zarówno na podstawie językowych, jak i pozajęzykowych dyrektyw interpretacji. Biorąc pod uwagę powyżej wyróżnione nurty, należy stwierdzić, że na obecnym etapie rozumienia wykładni w orzecznictwie sądowym obowiązywanie zasady, w myśl której jasny w swojej treści przepis nie wymaga wykładni, jest nadal mocno akcentowane. Pogląd uznający prymat wykładni językowej w procesie interpretacji, zarówno pod względem chronologicznym, jak i znaczeniowym, uzupełniany jest niekiedy odwołaniem się do reguł systemowych oraz funkcjonalnych. Stopniowo jednak uznanie zyskuje stanowisko, że zawsze w procesie interpretacji należy uwzględniać rezultaty pozajęzykowych dyrektyw wykładni, $\mathrm{w}$ tym dyrektyw funkcjonalnych.

V. Nieco odmienny obraz odwoływania się przez NSA do poszczególnych dyrektyw wykładni i ich znaczenia dla procesu interpretacji wynika $\mathrm{z}$ analizy jego działalności uchwałodawczej. Na przestrzeni ostatnich dwóch i pół roku, począwszy od 2009 r., NSA w podjętych w tym okresie 50 uchwałach w procesie interpretacji przepisów opierał się zarówno na językowych, jak i pozajęzykowych dyrektywach wykładni ${ }^{29}$, rzadko ograniczając proces interpretacji do jednoznacznego rezultatu wykładni językowej ${ }^{30}$. Pośród szeregu uchwał na szczególne wyróżnienie zasługuje pierwsza $\mathrm{w}$ historii sądownictwa administracyjnego uchwała pełnego składu NSA odnosząca się do problematyki podstaw kasacyjnych $\mathrm{w}$ postępowaniu sądowoadministracyjnym ${ }^{31}$. Osiągnięty rezultat wykładni systemowej i funkcjonalnej nie zawsze pozostawał przy tym zgodny z wynikiem wykładni językowej. Odwołując się do dyrektyw preferencji,

27 Wyroki: NSA z 23 marca 2011 r., sygn. akt I FSK 764/10, CBOSA; NSA z 3 listopada 2010 r., sygn. akt I FSK 1938/09, CBOSA; WSA w Szczecinie z 3 listopada 2010 r., sygn. akt I SA/Sz 519/10, CBOSA; NSA z 20 października 2010 r., sygn. akt II OSK 1678/09, CBOSA.

${ }^{28}$ Wyroki: WSA w Poznaniu z 1 czerwca 2011 r., sygn. akt IV SA/Po 254/11, CBOSA; WSA w Poznaniu z 3 listopada 2010 r., sygn. akt IV SA/Po 491/10, CBOSA.

${ }^{29}$ W ramach dyrektyw pozajęzykowych NSA odwoływał się między innymi do argumentacji o charakterze aksjologicznym, powiązanych z celem analizowanej regulacji prawnej i koniecznością jego uwzględnienia w ramach prima facie odmiennych rezultatów wykładni. Zob. uchwały NSA z 3 listopada 2009 r., sygn. akt II GPS 3/09, ONSAiWSA 2010/1/2 i z 26 października 2009 r., sygn. akt II FPS 2/09, ONSAiWSA $2010 / 1 / 3$.

${ }^{30}$ W uchwale z 18 listopada 2009 r., sygn. akt II OPS 4/09, ONSAiWSA 2010/1/5, NSA, dokonując wykładni art. 15 ust. 1 pkt 6 ustawy o broni i amunicji, doszedł do wniosku, że językowy rezultat interpretacji pozostaje na tyle oczywisty, że brak jest uzasadnienia, aby od niego odstąpić na rzecz innych rodzajów wykładni. Przy wykładni przepisu prawa jest bowiem zasadą, że nie powinno stosować się wykładni celowościowej, systemowej czy funkcjonalnej, jeżeli treść przepisu jest wystarczająco jednoznaczna.

${ }^{31}$ Uchwała NSA z 26 października 2009 r., sygn. akt I OPS 10/09, ONSAiWSA 2010/1/1 (dalej: uchwała pełnego składu NSA). W uchwale tej NSA, odwołując się do argumentów funkcjonalnych, zauważył, że celem skargi kasacyjnej pozostaje umożliwienie stronie niezadowolonej z wyroku, w którym sąd I instancji dokonał oceny naruszenia przepisów postępowania administracyjnego, weryfikacji prawidłowości oceny naruszenia właśnie owych przepisów postępowania administracyjnego dokonanej przez NSA w granicach zakreślonych podstawą kasacyjną wymienioną w art. 174 pkt 2 p.p.s.a. 
NSA nie przyjmował automatycznie nadrzędności rezultatu wykładni językowej nad dyrektywami pozajęzykowymi, ważąc za każdym razem osiągnięte wyniki wykładni i udzielając w ten sposób odpowiedzi na postawione pytanie prawne. Niejednokrotnie jednak rezultat wykładni językowej ustępował miejsca wykładni systemowej i funkcjonalnej ${ }^{32}$.

Bardziej regularne odwoływanie się w podejmowanych przez NSA uchwałach do dyrektyw pozajęzykowych należy tłumaczyć ich silną rolą perswazyjną oraz możliwością wprowadzenia w uchwałach quasi-oficjalnych reguł wykładni oraz reguł precedensowych przez wzmacnianie jednolitości orzecznictwa oraz uznawanie ustalonego orzecznictwa. Prawidłowo podjęte uchwały pełnia ponadto swoistą funkcję profilaktyczną, pozwalająca na uniknięcie ,,potencjalnych naruszeń obowiązującego porządku prawnego" ${ }^{33}$. Moc wiążąca uchwał NSA w postępowaniu sądowoadministracyjnym wynika $\mathrm{z}$ art. $269 \S 1$ p.p.s.a. Nie ulega wszakże wątpliwości, że oprócz mocy wiążącej uchwał nadanej im przez ustawodawcę, korzystają one również z tak zwanej intelektualnej mocy obowiązującej, zbudowanej na sile autorytetu sądu, który podejmuje uchwały, oraz na wskazanej w każdej uchwale argumentacji prawnej. Im mniej byłaby ona przekonująca, tym intelektualna moc obowiązująca uchwały traciłaby na znaczeniu. Uwzględnianie $\mathrm{w}$ dyskursie prawnym uchwały pozajęzykowych reguł wykładni sprzyja powiększeniu jej pozanormatywnej mocy obowiązującej.

VI. Odnosząc się do tego rodzaju reguł pozajęzykowych, sądy administracyjne, sięgając do rezultatów wykładni funkcjonalnej, każdorazowo staraja się wypełnić rozumienie kontekstu funkcjonalnego treścią istotną dla konkretnej rozpoznawanej sprawy. Wykładnia nie może sprowadzać się do szukania znaczenia poszczególnych zwrotów tekstu prawnego, lecz powinna być połączona $\mathrm{z}$ analizą celu regulacji prawnej ${ }^{34}$. Znaczącym źródłem, z którego sądy czerpią wiedzę na temat wartości preferowanych przez prawodawcę oraz ogólnie przyjmowanego kontekstu funkcjonalnego, są obowiązujące akty prawodawcze, wśród których istotne znaczenie odgrywa Konstytucja $\mathrm{RP}^{35}$,

${ }^{32}$ Przykładowo w uchwale z 10 grudnia 2009 r., sygn. akt I OPS 8/09, ONSAiWSA 2010, nr 2, poz. 21, NSA, dokonując wykładni użytego w art. 3 ust. 3 ustawy o dodatkach mieszkaniowych (Dz. U. Nr 71, poz. 734 ze zm.) sformułowania ,,zasiłki pielęgnacyjne”, oparł się na rezultatach wykładni systemowej i funkcjonalnej, dochodząc do ostatecznego wniosku, że dodatku pielęgnacyjnego, określonego w art. 75 ustawy z 17 grudnia 1998 r. o emeryturach i rentach z Funduszu Ubezpieczeń Społecznych (Dz. U. 2004, nr 39, poz. 353 ze zm.) nie wlicza się do dochodu, o którym mowa w art. 3 ust. 3 powyższej ustawy o dodatkach mieszkaniowych. Z kolei w uchwale z 15 czerwca 2011 r., sygn. akt I OPS 1/11, ONSAiWSA 2011, nr 5, poz. 95, NSA, dostrzegając niejednoznaczność pojęciową ,dnia ustawowo wolnego od pracy”, o którym stanowi art. $57 \S 4$ ustawy z 14 czerwca 1960 r. - Kodeks postępowania administracyjnego (tekst jedn.: Dz. U. 2000, Nr 98, poz. 1071 ze zm.; dalej: k.p.a.), w oparciu o reguły systemowe i funkcjonalne doszedł do przekonania, że sobota jest równorzędnym dniem z dniem ustawowo wolnym od pracy w rozumieniu art. $57 \S 4$ k.p.a.

${ }^{33}$ J. P. Tarno, Naczelny Sad Administracyjny..., s. 182; A. Skoczylas, Działalność uchwatodawcza Naczelnego Sadu Administracyjnego, Warszawa 2004, s. 20 i 25-26.

${ }^{34}$ Wyrok WSA w Poznaniu z 14 kwietnia 2011 r., sygn. akt III SA/Po 65/11, CBOSA.

35 Wyroki: WSA w Poznaniu z 15 czerwca 2011 r., sygn. akt IV SA/Po 386/11, CBOSA; NSA z 5 maja 2011 r., sygn. akt I OSK 167/11, CBOSA; WSA w Bydgoszczy z 19 kwietnia 2011 r., sygn. akt I SA/Bd 167/11, CBOSA; WSA w Gdańsku z 1 marca 2011 r., sygn. akt I SA/Gd 32/11, CBOSA; WSA w Gorzowie Wielkopolskim z 21 października 2010 r., sygn. akt II SA/Go 644/10, CBOSA; NSA z 24 sierpnia 2010 r., sygn. akt II OSK 1320/09, CBOSA; NSA z 22 października 2009 r., sygn. akt I OSK 351/09, CBOSA. 
regulacje prawne rangi ustawowej ${ }^{36}$, prawo unijne ${ }^{37}$, a także - chociaż w mniejszym zakresie - akty prawa miejscowego ${ }^{38}$. Aczkolwiek w tej mierze należy wyróżnić dwa sposoby odwoływania się przez sądy administracyjne do aktów prawnych znajdujących się na różnych poziomach struktury źródeł prawa, gdyż oprócz formułowania na ich podstawie wniosków natury funkcjonalnej, orzecznictwo sądowe odwołuje się do nich w ramach wykładni systemowej, tak aby wyinterpretowana norma prawna pozostawała w zgodności z aktami prawnymi wyższego $\mathrm{rzędu}^{39}$. Oceniając wartości wynikające $\mathrm{z}$ aktów prawnych, analizuje się również uzasadnienia projektów aktów prawodaw$\operatorname{czych}^{40}$, a niekiedy przebieg procesu legislacyjnego ${ }^{41}$.

Odwoływanie się przez składy orzekające sądów administracyjnych do genezy interpretowanego aktu prawnego stanowi przejaw sięgania do wykładni historycznej. W odmiennym znaczeniu wykładnia historyczna rozumiana jest jako powoływanie się na ewolucję uregulowań prawnych badanego zagadnienia $^{42}$. Dyrektywy historyczne należą przy tym do szeroko rozumianego kontekstu funkcjonalnego interpretowanej regulacji prawnej. Natomiast z przywołanych orzeczeń wynika, że są one traktowane niejako odrębnie, gdyż sądy, wskazując na dyrektywy historyczne, osobno zwracają uwagę na znaczenie reguł funkcjonalnych bądź celowościowych.

Niekiedy sądy odwołuja się do ogólnie przyjętych i akceptowanych reguł funkcjonowania rzeczywistości społecznej i gospodarczej, związanych z działalnością określonych podmiotów lub grup zawodowych, posiłkując się również w tym zakresie orzecznictwem innych składów orzekających czy innych sądów ${ }^{43}$. Ze względu na brzmienie art. 269 § 1 p.p.s.a. szczególne znaczenie dla

${ }^{36}$ Postanowienie NSA z 29 kwietnia 2011 r., sygn. akt II FZ 141/11, CBOSA oraz wyroki: NSA z 20 kwietnia 2011 r., sygn. akt I OSK 904/10, CBOSA; WSA w Lublinie z 2 grudnia 2010 r., sygn. akt I SA/Lu 487/10, CBOSA; WSA w Krakowie z 24 kwietnia 2009 r., sygn. akt I SA/Kr 338/09, CBOSA. $\mathrm{W}$ ramach regulacji ustawowej sądy odwołują się również do załączników ustawowych zawierających treść normatywną. Zob. wyrok WSA w Gdańsku z 21 stycznia 2010 r., sygn. akt I SA/Gd 841/09, CBOSA.

${ }^{37}$ Wyrok WSA w Poznaniu z 23 września 2010 r., sygn. akt I SA/Po 522/10, CBOSA.

${ }^{38}$ Wyrok WSA w Gdańsku z 11 sierpnia 2011 r., sygn. akt II SA/Gd 222/10, CBOSA.

${ }^{39} \mathrm{~W}$ odniesieniu do orzecznictwa SN uwagę taką sformułował A. Municzewski w monografii Reguty interpretacyjne $w$ dziatalności orzeczniczej Sadu Najwyższego, Szczecin 2004, s. 125.

${ }^{40}$ Zob. wyroki: WSA w Poznaniu z 17 lutego 2011 r., sygn. akt III SA/Po 678/10, CBOSA; WSA w Warszawie z 11 października 2010 r., sygn. akt IV SA/Wa 1517/10, CBOSA; NSA z 22 września 2010 r., sygn. akt II FSK 818/09, CBOSA; WSA w Opolu z 11 lutego 2009 r., sygn. akt I SA/Op 361/08, CBOSA.

${ }^{41}$ Wyrok WSA w Szczecinie z 16 czerwca 2011 r., sygn. akt I SA/Sz 168/11, CBOSA.

${ }^{42}$ O. Bogucki, M. Zieliński, Wyktadnia prawa we wspótczesnym orzecznictwie Trybunatu Konstytucyjnego, Sadu Najwyższego i Naczelnego Sadu Administracyjnego, w: L. Gardocki, J. Godyń, M. Hudzik, L. K. Paprzycki (red.), Orzecznictwo sqdowe w sprawach karnych. Aspekty europejskie $i$ unijne, Rajgród-Wilno 2008, s. 85-86. Do tak rozumianej wykładni historycznej NSA wielokrotnie odwołuje się w uzasadnieniach podejmowanych rozstrzygnięć. Zob. wyroki: WSA w Łodzi z 8 czerwca 2011 r., sygn. akt III SA/Łd 215/11, CBOSA; WSA w Krakowie z 26 maja 2011 r., sygn. akt I SA/Kr 562/11, CBOSA; WSA w Warszawie z 22 maja 2011 r., sygn. akt III SA/Wa 2493/10, CBOSA; NSA z 28 kwietnia 2011 r., sygn. akt II OSK 757/10, CBOSA; NSA z 8 kwietnia 2011 r., sygn. akt II FSK 2091/09, CBOSA; NSA z 16 marca 2011 r., sygn. akt I OSK 663/10, CBOSA.

${ }^{43}$ NSA w wyroku z 18 marca 2011 r., sygn. akt II FSK 1773/09, CBOSA, analizując współczesne działanie podmiotów gospodarczych, odwołał się do orzecznictwa ówczesnego Europejskiego Trybunału Sprawiedliwości poddającego analizie pojęcie oddziału przedsiębiorcy zagranicznego. Zob. też wyroki: 
podejmowanego rozstrzygnięcia mają przyjęte uchwały NSA. Sądy administracyjne, dokonując wykładni przepisów prawnych w konkretnej sprawie i mając na względzie uprzednio podjęte uchwały NSA obejmujące swoim zakresem badane zagadnienie prawne, $\mathrm{w}$ tej części odwołują się do rezultatów wykładni dokonanej przez NSA, czyniąc ją elementem swoich rozważań prawnych. Stworzenie takiego mechanizmu sprzyja jednolitości orzecznictwa sądowego przez odwołanie się do tych samych reguł wykładni. W tym miejscu należy dodać, że dla zachowania spójności orzecznictwa sądowego NSA, podejmując kolejne uchwały, odwołuje się niekiedy do uprzednio podjętych rozstrzygnięć tego samego rodzaju, co $\mathrm{w}$ sposób dodatkowy przemawia za zasadnością dokonanego w tych uchwałach procesu interpretacji ${ }^{44}$.

Specyficznym dla prawa administracyjnego źródłem, z którego sądy administracyjne dekoduja kontekst funkcjonalny rozstrzygnięcia, są ponadto ogólne założenia prawa administracyjnego $\mathrm{z}$ uwzględnieniem znaczenia istniejącego w nim władztwa administracyjnego ${ }^{45}$ oraz konieczności realizacji celu publicznego, który nie pozwala absolutyzować znaczenia wykładni językowej ${ }^{46}$. Należy jednakże dodać, że we wcześniejszym orzecznictwie sądowym zauważono, iż charakterystycznym założeniem dla wykładni prawa administracyjnego jest reguła, w myśl której interpretacja nie może być dokonana $\mathrm{w}$ taki sposób, aby przeczyła literze prawa ${ }^{47}$. Ponadto we współczesnym orzecznictwie sądów administracyjnych znaczącą rolę odgrywają zasady ogólne k.p.a. traktowane nieomal jako część ogólna całego prawa administracyjnego. Charakterystyczną cechą analizowanego orzecznictwa, zauważaną również przez przedstawicieli doktryny, pozostaje opieranie podejmowanych rozstrzygnięć bezpośrednio na Konstytucji RP, jako wyłącznej podstawie rozstrzygnięcia, czy też prokonstytucyjnym stosowaniu przepisów zamieszczonych w aktach prawnych niższego rzędu ${ }^{48}$. Przepisy konstytucyjne, zwykle dotyczące określonych celów bądź działalności państwa, powoływane sa w sytuacjach, gdy sąd ma wątpliwości co do rzeczywistej treści wykładanej normy prawnej. Modyfikacja czy odejście od - z pozoru jednoznacznego brzmienia przepisu prawnego w efekcie poddania go wykładni funkcjonalnej

WSA w Łodzi z 10 grudnia 2010 r., sygn. akt III SA/Łd 538/10, CBOSA; WSA we Wrocławiu z 7 grudnia 2010 r., sygn. akt II SA/Wr 221/10, CBOSA; WSA w Olsztynie z 30 kwietnia 2010 r., sygn. akt II SA/Ol $207 / 10$, CBOSA.

${ }^{44}$ NSA odwołał się do uchwały pełnego składu w uchwałach z 8 grudnia 2009 r., sygn. akt II GPS 5/09, ONSAiWSA 2010, nr 3, poz. 40 oraz z 28 czerwca 2010 r., sygn. akt II GPS 1/10, ONSAiWSA 2010, nr 5 , poz. 81 .

${ }^{45}$ Wyrok WSA w Krakowie z 4 lipca 2011 r., sygn. akt II SA/Kr 567/11, CBOSA.

${ }^{46}$ Wyrok WSA w Krakowie z 4 lipca 2011 r., sygn. akt II SA/Kr 567/11, CBOSA oraz z 16 czerwca 2010 r., sygn. akt II SA/Kr 626/09, CBOSA.

47 Wyrok WSA w Warszawie z 17 marca 2004 r., sygn. akt II SA 1933/03, CBOSA.

48 J. Trzciński, Bezpośrednie stosowanie zasad naczelnych Konstytucji przez sady administracyjne, „Zeszyty Naukowe Sądownictwa Administracyjnego” 2011, z. 3, s. 30-36. Jedną z form uwzględniania Konstytucji w orzecznictwie sądowym są formułowane przez poszczególne składy orzekające pytania prawne do Trybunału Konstytucyjnego w trybie art. 193 Konstytucji. W 2009 r. Trybunał Konstytucyjny rozstrzygnął 11 spraw zainicjowanych pytaniami prawnymi. Zob. Informacja o dziatalności sadów administracyjnych w 2009 r., Warszawa 2010, s. 219-227. Natomiast w 2010 r. Trybunał rozstrzygnął 15 pytań prawnych skierowanych przez sądy administracyjne. Aktualnie w Trybunale 20 pytań prawnych pochodzących od sądów administracyjnych oczekuje na rozstrzygnięcie. Zob. Informacja o dziatalności sqdów administracyjnych w 2010 r., Warszawa 2011, s. 218-221. 
jest niekiedy skutkiem odwołania się przez sąd do określonych zasad czy wartości konstytucyjnych. Podobne zjawisko odnotowuje się przy stosowaniu przez sądy orzecznictwa Trybunału Konstytucyjnego, nawet w sytuacji gdy określony wyrok Trybunału nie dotyczył przepisu stosowanego $\mathrm{w}$ danej sprawie $^{49}$. Częste odwoływanie się $\mathrm{w}$ orzecznictwie sądowym do Konstytucji wynika z zależności istniejących pomiędzy prawem konstytucyjnym a administracyjnym, należącymi do prawa publicznego. Jak wskazywał S. Kasznica, nie istnieje pewne kryterium, według którego można by przeprowadzić wyraźną linię działową pomiędzy tymi dwoma dziedzinami ${ }^{50}$. Wykładnia celowościowa jest również dekodowana $\mathrm{z}$ uwzględnieniem założeń przyjmowanych przez prawodawcę unijnego ${ }^{51}$. Sędzia sądu administracyjnego jako sędzia europejski zobowiązany jest do dokonywania wykładni prounijnej - uwzględniania zarówno aktów prawnych bezpośrednio stosowanych na terytorium państw członkowskich ${ }^{52}$, aktów prawnych wymagających implementacji do krajowych porządków prawnych ${ }^{53}$, jak i orzecznictwa organów sądowych, w tym przede wszystkim Trybunału Sprawiedliwości Unii Europejskiej ${ }^{54}$. Ponadto ze względu na rozbudowany w prawie unijnym sposób formułowania preambuł wykładnia funkcjonalna nabiera istotnego znaczenia dla jego stosowania przez sąy administracyjne. Poza tym, biorąc pod uwagę stopniowe poszerzanie się zakresu regulacji normowanej przez prawo unijne, który w ramach prawa administracyjnego obejmuje szerokie spektrum materialnoprawne, jego wpływ na cały proces wykładni dokonywanej przez sądy administracyjne w chwili obecnej pozostaje znaczący i należy domniemywać, że będzie stopniowo poszerzany ${ }^{55}$.

${ }^{49}$ Informacja o działalności sqdów administracyjnych w 2009 r., Warszawa 2010, s. 234-235.

${ }^{50}$ S. Kasznica, Polskie prawo administracyjne. Pojęcia i instytucje zasadnicze, Poznań 1946, s. 20-21. Zob. też Z. Duniewska, Prawo administracyjne..., s. 171-177; W. Jakimowicz, Wyktadnia ..., s. 166-167.

${ }^{51}$ Zob. wyroki: WSA w Gorzowie Wielkopolskim z 16 czerwca 2011 r., sygn. akt I SA/Go 408/11, CBOSA; WSA z 23 marca 2011 r., sygn. akt III SA/Wa 1615/10, CBOSA; NSA z 23 marca 2011 r., sygn. akt I GSK 132/10, CBOSA; WSA z 23 listopada 2009 r., sygn. akt III SA/Wa 1369/09, CBOSA.

${ }^{52} \mathrm{~W}$ tym zakresie na uwagę zasługuje wyrok NSA z 24 lutego 2009 r., sygn. akt II OSK 223/08, CBOSA, w którym NSA, analizując zakres oraz znaczenie zasady swobody prowadzenia działalności gospodarczej, zauważył, że podstawowym aktem prawnym regulującym prawa i obowiązki obywateli państw członkowskich WE jest Traktat ustanawiający Wspólnotę Europejską.

${ }^{53}$ Przykładem odwołania się w omawianym zakresie do prawa unijnego jest wyrok WSA w Gdańsku z 5 marca 2009 r., sygn. akt III SA/Gd 459/08, CBOSA, w którym sąd ten, kontrolując legalność rozstrzygnięć organów Służby Więziennej w przedmiocie udzielenia funkcjonariuszowi (będącemu lekarzem) czasu wolnego od pracy, odwołał się do kontekstu funkcjonalnego dyrektywy Parlamentu Europejskiego i Rady nr 2003/88/WE z 22 czerwca 2002 r. dotyczącej niektórych aspektów organizacji czasu pracy. Sąd zwrócił w tym zakresie uwagę, że celem dyrektywy regulacji zastosowanej w sprawie jest zapewnienie bezpieczeństwa, higieny i ochrony zdrowia pracowników, a środkiem prowadzącym do tego celu jest organizacja pracy zapewniająca odpowiedni czas odpoczynku.

${ }^{54}$ Jednym z przejawów odwoływania się przez sądy administracyjne do orzecznictwa Trybunału Sprawiedliwości Unii Europejskiej pozostaja formułowane pytania prejudycjalne. W $2009 \mathrm{r}$. sądy administracyjne sformułowały pięć pytań tego rodzaju, zob. Informacja o działalności sadów administracyjnych $w 2009$ r., s. 174-179, natomiast w 2010 r. sądy zdecydowały się w dziewięciu sprawach sformułować pytania prejudycjalne, zob. Informacja o działalności sadów administracyjnych w $2010 \mathrm{r}$., s. 194-196.

${ }^{55}$ Tego rodzaju wniosek pojawia się w opracowywanych przez pracowników Biura Orzecznictwa NSA analizach podsumowujacych orzecznictwo w danym roku kalendarzowym. Zob. Informacja o dziatalności sqdów administracyjnych w 2009 r., s. 217-218; Informacja o dziatalności sadów administracyjnych $w 2009$ r., s. 217. 
Zaprezentowane powyżej rozważania dotyczące sposobu dekodowania kontekstu funkcjonalnego w poszczególnych orzeczeniach uwidoczniły również niekonsekwencję $\mathrm{w}$ sposobie posługiwania się przez sądy administracyjne terminami związanymi $\mathrm{z}$ wykładnią funkcjonalna. $\mathrm{Na}$ problem ten zwrócił uwagę również O. Bogucki wskazując, że tego rodzaju niekonsekwencja skutkuje powstaniem niejasności co do przyjmowanej relacji pomiędzy wykładnią celowościową a wykładnią funkcjonalną ${ }^{56}$.

VII. Przechodząc do analizy znaczenia wyniku wykładni funkcjonalnej dla ostatecznego rezultatu wykładni, odwoływanie się do reguł funkcjonalnych może - po pierwsze - dodatkowo potwierdzić wynik interpretacji językowej, po drugie - przesądzić o wyborze jednego z dopuszczalnych na gruncie językowym rezultatu wykładni, a po trzecie - skutkować korektą językowego wyniku wykładni przez jego pominięcie i zastąpienie rezultatami wykładni systemowej i funkcjonalnej ${ }^{57}$. Potwierdzenie otrzymanego wyniku wykładni językowej skutkuje ugruntowaniem osiągniętego rezultatu i przemawia za jego prawidłowością. Modyfikacja wyniku interpretacji językowej może przybrać dwojaka postać. Z jednej strony prowadzi do wyboru jednego z dopuszczalnych z językowego punktu widzenia jego rezultatów, z drugiej - skutkuje działaniem negatywnym, prowadzącym do eliminacji poszczególnych wyników językowych sprzecznych z przyjętym kontekstem funkcjonalnym i wyboru tego rezultatu, który pozostaje z nią koherentny. Odwołanie się do rezultatu wykładni funkcjonalnej może doprowadzić nadto do zawężenia albo poszerzenia zakresu zastosowania albo normowania danej normy prawnej, czy też odwołania się do wykładni a simili ${ }^{58}$ bądź a contrario ${ }^{59}$. Analizując sytuacje, w których orzecznictwo sądowe odstępuje od rezultatu wykładni językowej, szczególną uwagę należy zwrócić na takie przypadki, w których pozostaje on w sprzeczności z wartościami konstytucyjnymi ${ }^{60}$. W dalszej kolejności sądy odstępują od osiagnniętego rezultatu wykładni językowej, jeśli prowadzi on do niedorzeczności ${ }^{61}$. Warto również zauważyć, że argumenty wynikające z wykładni

${ }^{56}$ O. Bogucki, op. cit., s. 230-233.

${ }^{57}$ Wyroki: WSA w Poznaniu z 1 czerwca 2011 r., sygn. akt IV SA/Po 254/11, CBOSA; WSA w Gliwicach z 11 stycznia 2011 r., sygn. akt IV SA/Gl 467/10, CBOSA; WSA w Gliwicach z 9 listopada 2010 r., sygn. akt IV SA/Gl 276/10, CBOSA; WSA w Gliwicach z 12 lutego 2010 r., sygn. akt III SA/Gl 1060/09, CBOSA.

${ }^{58}$ Zob. wyrok WSA w Gorzowie Wielkopolskim z 26 marca 2009 r., sygn. akt I SA/Go 65/09, CBOSA.

${ }^{59}$ Zob. wyroki NSA: z 17 lutego 2010 r., sygn. akt I OSK 1302/09, CBOSA; z 8 października 2009 r., sygn. akt I FSK 728/09, CBOSA; z 3 września 2009 r., sygn. akt II OSK 1872/08, CBOSA. Warto w tym miejscu zauważyć, że sądy administracyjne częściej odwołują się do wykładni a contrario, aniżeli a simili, co wiąże się niewątpliwie z kontrowersyjnością odwoływania się na gruncie prawa administracyjnego do analogia legis. Natomiast stosunkowo najczęściej do wykładni a contario nawiązują skarżący, zarówno inicjując postępowanie sądowoadministracyjne, jak i korzystając ze środków zaskarżenia.

${ }^{60}$ Wyroki: WSA w Kielcach z 29 grudnia 2010 r., sygn. akt II SA/Ke 761/10, CBOSA; WSA w Rzeszowie z 14 grudnia 2010 r., sygn. akt II SA/Rz 969/10, CBOSA; WSA w Krakowie z 7 grudnia 2010 r., sygn. akt III SA/Kr 931/10, CBOSA; WSA w Bydgoszczy z 19 października 2010 r., sygn. akt II SA/Bd 974/10, CBOSA.

${ }^{61}$ Przy czym sama niedorzeczność osiągniętego rezultatu wykładni językowej bywa różnie rozumiana. $\mathrm{Z}$ jednej strony wskazuje się, że polega ona na sprzeczności z ratio legis interpretowanych przepisów, na sankcjonowaniu oczywistego błędu legislacyjnego czy też sprzeczności z podstawowymi wartościami aksjologicznymi przyjmowanymi przez prawodawcę. Zob. wyrok NSA z 8 kwietnia 2011 r., 
funkcjonalnej bardzo często powoływane sa $\mathrm{w}$ powiązaniu $\mathrm{z}$ dyrektywami systemowymi, wzajemnie wspierając pozajęzykowy rezultat interpretacji ${ }^{62}$. Orzeczenia, w których sąd w procesie wykładni dokonywałby przeciwstawienia sobie dyrektyw systemowych i funkcjonalnych, w praktyce orzeczniczej nie sa spotykane.

VIII. Reasumując poczynione uwagi - po pierwsze - trzeba zauważyć, że dominującym nurtem $\mathrm{w}$ orzecznictwie sądowym jest odwoływanie się do językowych rezultatów procesu interpretacji, co w szeregu orzeczeń zostało połaczone wprost z sięgnięciem do paremii clara non sunt interpretanda. Swiadczy to o pierwszeństwie wykładni językowej nie tylko pod względem chronologicznym, lecz także znaczeniowym. W tym ujęciu odwoływanie się do rezultatów wykładni funkcjonalnej, o ile w ogóle nie zostało uznane za zbyteczne, służy potwierdzeniu otrzymanego rezultatu wykładni językowej albo dokonaniu wyboru spośród dopuszczalnych jej rezultatów.

Po drugie, istotnego znaczenia nabiera coraz powszechniejsze odwoływanie się przez sądy administracyjne do konkretnych dyrektyw funkcjonalnych. Nie bez znaczenia dla tej praktyki pozostaje działalność uchwałodawcza NSA, w której nieomal regułą jest uwzględnianie w procesie interpretacji przepisów prawnych rezultatów pozajęzykowych dyrektyw wykładni. Nie jest ono jednak powiązane $\mathrm{z}$ wypracowaniem jednolitego oraz kompletnego modelu dokonywania wykładni funkcjonalnej.

Po trzecie, wykładnia funkcjonalna w orzecznictwie sądów administracyjnych odnoszona jest przede wszystkim do aktów prawnych, wśród których podstawowe znaczenie ma Konstytucja RP, regulacje rangi ustawowej oraz podustawowej, w tym akty prawa miejscowego oraz prawo unijne. Przedstawione źródła dekodowania kontekstu funkcjonalnego wiążą się ze specyfiką prawa administracyjnego, dla którego wyszczególnione powyżej akty prawne odgrywają istotną rolę ${ }^{63}$.

Po czwarte, nie bez znaczenia pozostają te orzeczenia sądów administracyjnych, w których prymat - w ostatecznym rozstrzygnięciu sprawy zyskały

sygn. akt II FSK 2071/09, CBOSA. Przykładem tego rodzaju oparcia rozstrzygnięcia na wykładni funkcjonalnej, z pominięciem rezultatu wykładni językowej art. 84 ust. 3 pkt 2 ustawy - Prawo o ruchu drogowym (tekst jedn.: Dz. U. 2005, Nr 108, poz. 908 ze zm.), jest wyrok WSA w Poznaniu z 15 czerwca 2011 r., sygn. akt IV SA/Po 386/11, CBOSA, w którym sąd uchylił decyzję Samorządowego Kolegium Odwoławczego utrzymująca w mocy decyzję Starosty, odmawiającą cofnięcia diagnoście uprawnień do wykonywania badań technicznych pojazdów ze względu na konieczność odsunięcia od czynności diagnostycznych osób, które nie daja gwarancji ich wykonywania w sposób rzetelny. Stwierdziwszy w sposób ewidentny naruszenie prawa po stronie diagnosty, skutkujące powstaniem wątpliwości dotyczących prawidłowego wypełniania nałożonych na niego obowiązków, organy nie powinny były ograniczać swoich rozważań jedynie do formalnoprawnego zagadnienia braku przeprowadzenia kontroli, która powinna wykazać określone nieprawidłowości, ale powinny były dla oceny zasadności pozbawienia diagnosty uprawnień do wykonywania badań technicznych wziąć pod uwagę wyrok skazujący diagnostę na karę pozbawienia wolności.

${ }^{62}$ Wyrok WSA w Krakowie z 24 kwietnia 2009 r., sygn. akt I SA/Kr 338/09, CBOSA.

${ }^{63}$ Warto w tym miejscu podkreślić, że NSA, począwszy od 1980 r., w sposób znaczący opierał podejmowane rozstrzygnięcia na regulacji konstytucyjnej, co w istotny sposób wpłynęło na rozumienie podstawowych instytucji oraz konstrukcji prawa administracyjnego. Zob. J. P. Tarno, Naczelny Sad Administracyjny..., s. 134-137. 
dyrektywy funkcjonalne. W ten sposób sądy, odwołując się do szeroko rozumianych argumentów aksjologicznych, potrafiły w drodze interpretacji uzyskać normę prawną, która pozostawała z nimi w zgodności.

Uwzględnianie reguł funkcjonalnych $\mathrm{w}$ orzecznictwie sądowym czyni jego rezultat bardziej przemyślanym, pogłębionym, a przez to potwierdza jego prawidłowość. Dlatego nie należy a priori ograniczać procesu wykładni prawa administracyjnego do kontekstu językowego, gdyż osiągnięty w ten sposób rezultat może być nie do zaakceptowania dla podmiotu dokonującego interpretacji ze względu na racje systemowe lub funkcjonalne, czego dowodem sa powołane orzeczenia sądów administracyjnych. Przemawia za tym również sam przedmiot regulacji prawa administracyjnego, jako najobszerniejszej gałęzi prawa, współtworzonej przez szereg podmiotów posiadających kompetencje prawotwórcze. $\mathrm{Z}$ tego powodu $\mathrm{w}$ doktrynie prawa administracyjnego zwraca się uwagę na zawodność sięgania do paremii clara non sunt interpretanda ze względu na funkcje prawa administracyjnego oraz charakter jego norm, wyposażających organy administracji publicznej w kompetencje władcze ${ }^{64}$. Odwoływanie się do dyrektyw funkcjonalnych powinno stanowić nieodłączny element każdego rozumowania nastawionego na sformułowanie zwrotu stosunkowego o zgodności bądź niezgodności z prawem kontrolowanego aktu lub innej czynności z zakresu administracji publicznej. Innym zagadnieniem pozostaje natomiast każdorazowa potrzeba przeniesienia przeprowadzonego toku rozumowania do pisemnego uzasadnienia zapadłego orzeczenia, tak aby $\mathrm{z}$ jednej strony było ono zupełne, a z drugiej - przejrzyste i czytelne.

\title{
dr Wojciech Piatek
}

Uniwersytet im. Adama Mickiewicza w Poznaniu

wojtek@amu.edu.pl

\section{FUNCTIONAL INTERPRETATION OF JUDICIAL DECISIONS OF ADMINISTRATIVE COURTS}

\author{
Summary
}

The paper deals with the analysis of functional interpretation of judicial decisions of administrative courts made from 2009 to the middle of 2011. The function of the norms of administrative law that equip organs of public administration with competence and authority make functional rules of material importance in the construction of administrative law.

Currently, the main approach adopted by judges in making judicial decisions is to base them on linguistic interpretation only. Such an approach is a consequence of the existing scope of cognition of Polish administrative courts. However, an opinion that a systematic and functional interpretation should be applied in each interpretation process is gradually gaining recognition. A different conclusion comes from the analysis of the resolutions passed by the Supreme Administrative Court, which form extensive legal argumentation and interpretation of certain legal issues, frequently taking into account the non-linguistic interpretation as well.

Functional rules should be an inseparable element of reasoning in each judicial process leading to a judicial decision or a formulation of a statement of the legality of a public administrative act.

${ }^{64}$ Zob. E. Smoktunowicz, Clara non sunt interpretanda $w$ prawie administracyjnym, w: Z. Chmiel (red.), Księga pamiatkowa Profesora Eugeniusza Ochendowskiego, Toruń 1999, s. 304; K. Lewandowska, T. Lewandowski, Wyktadnia celowościowa..., s. 23; Z. Kmieciak, Glosa do wyroku NSA $z$ dnia 30 marca 2004 r., sygn. akt FSK 154/04, OSP 2005, nr 6, poz. 73, s. 307. 
